NBER WORKING PAPER SERIES

ISRAEL'S IMMIGRATION STORY:

GLOBALIZATION LESSONS

\author{
Assaf Razin \\ Working Paper 23210 \\ http://www.nber.org/papers/w23210 \\ NATIONAL BUREAU OF ECONOMIC RESEARCH \\ 1050 Massachusetts Avenue \\ Cambridge, MA 02138 \\ March 2017
}

The views expressed herein are those of the author and do not necessarily reflect the views of the National Bureau of Economic Research.

NBER working papers are circulated for discussion and comment purposes. They have not been peer-reviewed or been subject to the review by the NBER Board of Directors that accompanies official NBER publications.

(C) 2017 by Assaf Razin. All rights reserved. Short sections of text, not to exceed two paragraphs, may be quoted without explicit permission provided that full credit, including $\odot$ notice, is given to the source. 
Israel's Immigration Story: Globalization Lessons

Assaf Razin

NBER Working Paper No. 23210

March 2017

JEL No. F02,F22,J1

\begin{abstract}
The exodus of Soviet Jews to Israel in the 1990s was a unique event. The extraordinary experience of Israel, which has received migrants from the Former Soviet Union (FSU) at the rate of 17 percent of its population, within a short time, is also relevant for the current debate about migration and globalization. The immigration wave was distinctive for its large high skilled cohort, and its quick integration into the domestic labor market. Among various ethnic groups the FSU immigrants ranked at the top of intergenerational upward mobility. Immigration also changed the entire economic landscape: it raised productivity, underpinning technological prowess, and had significant impact on income inequality and the level of redistribution in Israel's welfare state.
\end{abstract}

Assaf Razin

Eitan Berglas School of Economics

Tel Aviv University

Tel Aviv 69978

ISRAEL

and Cornell University and CEPR

and also NBER

ar256@cornell.edu

A data appendix is available at http://www.nber.org/data-appendix/w23210 


\title{
Israel's Immigration Story: Globalization lessons
}

By

Assaf Razin

Tel Aviv University,

Tel Aviv, Israel, www.tau.ac.il/ razin

\begin{abstract}
$\underline{\text { Abstract }}$
The exodus of Soviet Jews to Israel in the 1990s was a unique event. The extraordinary experience of Israel, which has received three quarter million migrants from the Former Soviet Union within a short time, is also relevant for the current debate about globalization. The immigration wave was distinctive for its large high skilled cohort, and its quick integration into the domestic labor market. Immigration also changed the entire economic landscape: it raised productivity, underpinning technological prowess, and had significant impact on income inequality and the level of redistribution in Israel's welfare state.
\end{abstract}

\section{Background}

Immigration has far-reaching economic and social consequences. These include the labor market, international trade, economic growth, the social and political structure, etc. (see, e.g., Lucas (2014) for a recent treatise), as has long been known. Between 1990 and 2012 almost $20 \mathrm{~m}$ people moved from Central, Eastern and South-Eastern Europe to richer countries in Western Europe, about 8 percent of the population of Europe. This east-west migration accelerated after 2004 when eight eastern European countries, including Poland, the Czech Republic and Hungary, joined the EU. At the same time Israel received almost $1 \mathrm{~m}$ 
immigrants, about 20 percent of Israel's population. In both episodes migration borders restrictions were eased. Both in the Israeli case and within the EU's borders is the free movement of people tied to the free movement of trade and capital. However, key differences between the two episodes, in addition to the relative size of the flow of migrants, are in the skill levels of the immigrants and the migrant-absorption policies that the receiving countries embraced.

The unique experience of Israel is vastly different for continuing of the globalization effort, not only from the recent experience in Europe, but also from the US experience. The core of the "wall-building" coalition in the US is white males with low educational attainment. Low income British were far more likely to support Brexit in the UK. The call for a "points based" immigration system from the Brexit campaign was an explicit call to increase the skill composition of UK immigrants. How does one explain the recent anti-immigration sentiment by a simple argument based on first principles? Low-skilled immigrants compete for low skill native-born jobs, and depress their wages. Furthermore, low-skilled immigrants are also more likely to be net beneficiaries from the typically generous welfare state; the burden of which low-skilled workers share. In contrast, high-skill immigrants may increase the productivity of the low-skilled population and are net fiscal contributors, making them a more attractive form of immigration. Low-skill segment of the destination-country established population.

Therefore, net fiscal burden involves the discontents with immigration, and would push to tilt the composition of immigration toward high-skilled workers. Other groups are more likely to gain from low-skilled immigration. They increase the wages of high-skill workers and do not necessarily impose a fiscal burden on retirees, who no longer fund the welfare state.

Therefore high skill workers support the globalization course that advanced economies have taken until the more recent wave of anti-immigration sentiment. In Israel, as we will see, the political-economy major effect of the 1990 s-early 2000 s migration wave is on income 
inequality through the downsizing of the welfare state. But, partly because of successful integration, no significant anti-migration sentiments emerged.

The exodus of Soviet Jews to Israel in the 1990s, especially its impacts on income inequality and the political balance of power vivifies Lucas's findings. ${ }^{1}$ Israel is already well known for the unique ways it absorbs immigrants; who in turn tend to arrive in waves triggered by external shocks. Each wave has its unique origin, distribution of skills, and often socio-economic characteristics. Thus, the exodus of Soviet Jews in the 1990s adds useful insights into this ongoing experiment.

The importance of the Soviet Jewish exodus is perhaps best appreciated in historical perspective. Immigration to the pre-state Palestine and to the state of Israel came in waves from the late 19 th century onwards. ${ }^{2}$ During the pre-state era (prior to 1948), immigration was at times controlled by the British rulers. ${ }^{3}$ However, immigration was free, and even encouraged, under the umbrella of the "Law of Return". Table 2.1 suggests that immigration at times, especially in the nascent statehood and in the last wave from the Former Soviet Union (FSU) constitutes about $20 \%$ of the established population.

\footnotetext{
${ }^{1}$ Benhabib and Jovanovich (2012) consider world-welfare perspective. Our analysis focuses on an individual state.

${ }^{2}$ See Razin and Sadka (1993)

${ }^{3}$ After World War One the League of Nations granted Great Britain a mandate over the whole of Palestine. It ended in May 1948, when Israel gained its independence.
} 
Table 2.1: Immigration, 1922-2001

\begin{tabular}{ccc}
\hline & $\begin{array}{c}\text { Immigrants as a } \\
\text { Percentage of } \\
\text { Established } \\
\text { Population }\end{array}$ & $\begin{array}{c}\text { Annual } \\
\text { Percentage } \\
\text { Growth Rate of } \\
\text { Population }\end{array}$ \\
\hline $1922-32$ & 8.2 & 8.0 \\
$1932-47$ & 6.4 & 8.4 \\
$1947-50$ & 19.8 & 21.9 \\
$1950-51$ & 13.2 & 20.0 \\
$1951-64$ & 2.2 & 4.0 \\
$1964-72$ & 1.3 & 3.0 \\
$1972-82$ & 0.9 & 2.1 \\
$1982-89$ & 0.4 & 1.8 \\
$1989-2001$ & 19.0 & 2.9 \\
\hline
\end{tabular}

Source: Ben-Porath (1985) for the years 1922-1982, Central Bureau of Statistics (1992), Bank of Israel (1991b) for the years 1982-2001.

Soviet-Jew immigration of the 1990s stands out from previous waves both because of its sheer volume and because the economic motivation. The choice, albeit limited by immigration restrictions of the advanced countries in the West: Australia, Canada, Germany, was between Israel and the rest, and US. In fact for a portion of would be immigrants, Israel was a second- choice.

\section{Migration-Pull Forces}

The disunion of the Soviet Union and the destruction of communism in the USSR 1987-1991 triggered the recent wave of Soviet Jews (Figure 2.1) to various parts of the world, including Israel. 
Figure 2.1: Emigration of Jews and their family members from the former USSR to Israel, USA and Germany (left axis, thousands) and the fraction of Jews in Israel (right axis, percent)

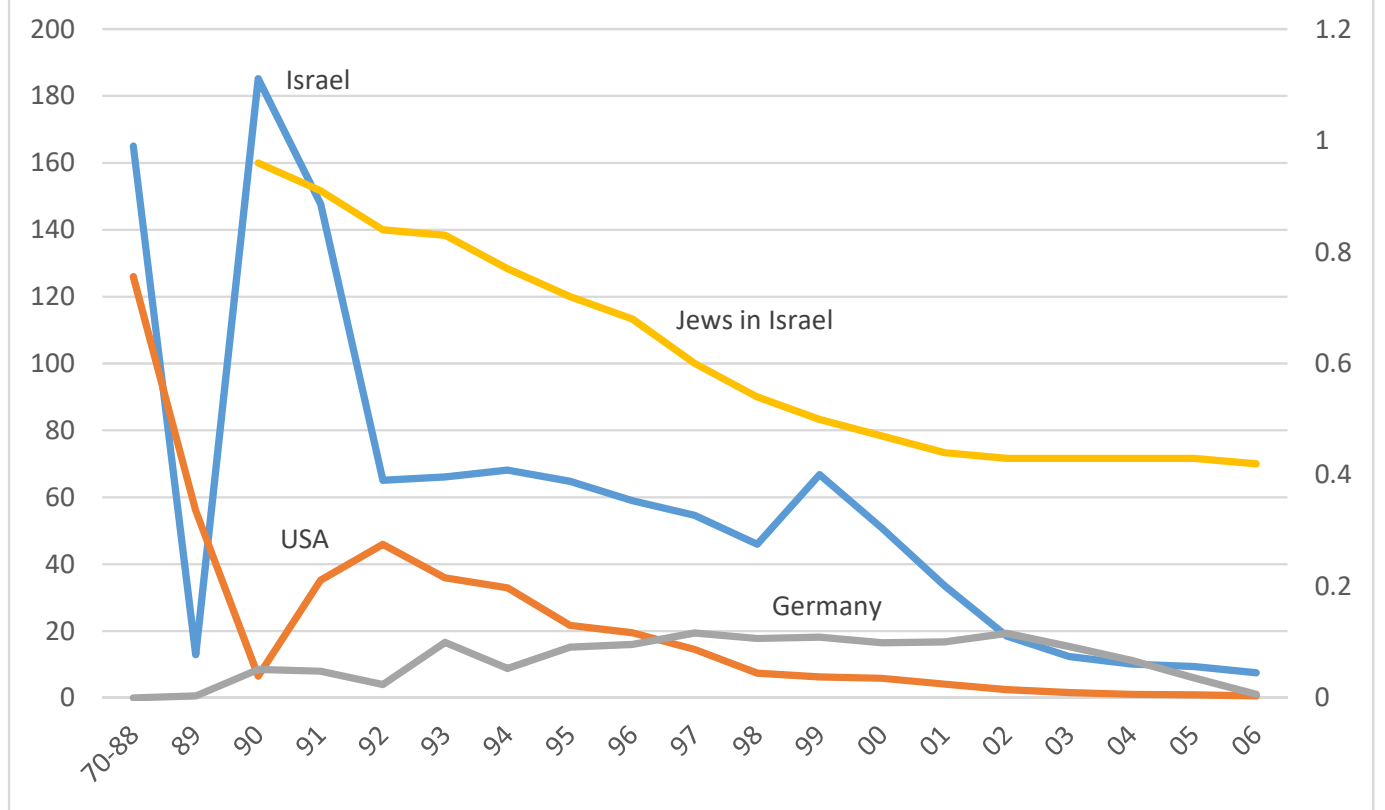

Source: http://demoscope.ru/weekly/2012/0497/demoscope497.pdf

All the migrant-destinations were controlled by the migration policies of the receiving countries; except Israel. Immigration into Israel is free by the Law of Return.

The primary driver of Jewish exodus from Russia 1990-1996 was the Soviet Union's and subsequently Russia's economic collapse, often-dubbed "katastroika". The Jewish community sensed the pain, anticipated the danger and fled for this compelling reason, but also due to the twin threats of a military coup d'tat and civil war. Both the demise of the Soviet Union and the following exodus in a macroeconomic jargon is a supply side shock, which triggers sizeable migration flows. The communist regime inaugurated a liberalization campaign in the political ("demokratizatsiya"), economic ("perestroika"), social and international spheres ("novoe myshlenie") that expanded opportunities of many, including the 
Soviet Jews to increase their welfare. ${ }^{4}$ However, they were legally barred from leaving the country until the complete demise of the regime. The prospect of brighter tomorrows in more stable and advanced, reinforced by mounting political, social and economic turmoil which raised the risk of civil war, created the specter of a military coup d'etat, threatened economic collapse.

The Soviet-Union economy ceased growing in 1989 and then plummeted nearly 10 percent in 1990 as enterprise managers focused on privatizing state assets to themselves ("spontaneous privatization"), liquidating them and transferring balances abroad instead of dedicating them to current operations. ${ }^{5}$ Inter-industrial supplies, the backbone of modern economies were shattered because managers ignored their contractual obligations to intermediate input users.

This was shock therapy in action without Sachs's conditionality. ${ }^{6}$ In theory, Soviet managers who had no experience designing and marketing products to satisfy consumer demand were expected to transform themselves into efficient competitors under duress. However, they could not do it. The reality was an economic depression that caused GDP to fall between 37 and 50 percent between 1989 and 1998. ${ }^{7}$ Full economic recovery was not achieved until 2006.

The Soviet Union's crumbling sphere of influence in Central Europe and East Germany, together with the successful secession of the Baltic States alerted the Russian Jewish community to the wisdom of carpe diem. A window of opportunity had opened, and Jewish emigres of the 1990s chose to seize the day. Migration waves and growth: bird's eye

\footnotetext{
${ }^{4}$ The first hint came in the enterprise reform law of January 1988, which allowed state enterprise managers to use company funds at their discretion instead of complying strictly with central plans ("tekhpromfinplans"). Soon thereafter, central plans ceased being obligatory. The stated intention of the enterprise reform law was to give managers more latitude in dealing with day-to-day operations, but the opportunity to divert funds from operations and investment to personal consumption and round-a-about insider privatization was not missed ("kleptostroika").

${ }^{5}$ Khoziastvo (1990).

${ }^{6}$ Sachs (2012).

${ }^{7}$ Rosefielde and Hedlund (2009).
} 
One of the most distinctive features associated with the Aliah waves is the high rates of economic growth. ${ }^{8}$ See Table 2.3 .

Table 2.3: Aliyah and Growth, 1922-2015 (annual percentage growth rates)

\begin{tabular}{|c|c|c|c|c|c|}
\hline Period & $\begin{array}{l}\text { Olim as a } \\
\text { percentage } \\
\text { of } \\
\text { established } \\
\text { population }\end{array}$ & $\begin{array}{l}\text { Population } \\
\text { Growth } \\
\text { rate }\end{array}$ & $\begin{array}{l}\text { Capital stock } \\
\text { growth rate } \\
\text { (excluding } \\
\text { housing) }\end{array}$ & $\begin{array}{l}\text { Housing } \\
\text { Stock } \\
\text { Growth rate }\end{array}$ & $\begin{array}{l}\text { Per capita } \\
\text { Output } \\
\text { growth rate } \\
\text { (not } \\
\text { cyclically } \\
\text { adjusted) }\end{array}$ \\
\hline $1922-1931$ & 9.5 & 8.0 & --- & --- & 7.8 \\
\hline $1932-1946$ & 15.6 & 8.4 & --- & --- & 3.0 \\
\hline $1947-1949$ & 37.7 & 21.9 & --- & --- & --- \\
\hline $1950-1951$ & 26.1 & 20.0 & --- & --- & 10.0 \\
\hline $1952-1963$ & 19.4 & 4.0 & 12.8 & 11.6 & 4.9 \\
\hline $1964-1971$ & 8.3 & 3.0 & 8.7 & 7.7 & 5.5 \\
\hline $1972-1982$ & 7.6 & 2.1 & 6.1 & 7.7 & 0.8 \\
\hline 1983-1989 & 2.7 & 1.8 & 3.1 & 4.0 & 3.1 \\
\hline $1990-2001$ & 16.5 & 3.0 & 7.0 & 4.7 & 2.5 \\
\hline $2002-2007$ & 1.9 & 1.8 & 2.4 & 2.5 & 1.9 \\
\hline $2008-2015$ & 1.8 & 2.0 & 3.4 & 3.2 & 1.3 \\
\hline
\end{tabular}

\footnotetext{
${ }^{8}$ Although the table alludes to simple correlation between migration and growth, the migration-wave shocks are considered to be an exogenous variable; a migration-push factor triggered by forces in the origin country. .See Neuman (1999).
} 
Source: Ben Porath (1985) for the years 1922-82. Central Bureau of Statistics (2016) and Bank of Israel (2016).

Table 2.3 indicates that the Alyiah produced massive investments, both in residential structures and in non-residential capital. These investments were so substantial that they increased the capital to labor ratio and facilitated economic growth. In some cases further aided by the remarkable human capital brought by the olim. Except for the olim who came during the major wave of Aliyah immediately after the birth of the state of Israel, the education level of the olim generally exceeded that of the established population and thus contributed remarkably to overall productivity. It is also noteworthy that in general the massive investments in physical capital and infrastructures were financed by capital imports (reflected in persistent current account deficit), as the olim themselves fled their former homes almost penniless and credit constrained so that they hardly saved. Table 2.3 shows, for instance, that during the years $1922-$ 31 , when the number of olim each year was about 9.5 percent of the established population, output increased at the whopping rate of about $16.4 \%$ per annum, so that output per capita increased by a remarkable $7.8 \%$ per annum. Similarly, during the years 1950-51, when the percentage of olim each year amounted to about $26.1 \%$ of the established population, output increased by about $10 \%$ per annum. During the years 1952-63, when the percentage of olim each year amounted to about $19.4 \%$, output growth was steady, 4.9 percent per anuum. In this period, capital stock growth rate was $12.8 \%$ and housing stock by 11.6 percent-- a whopping investment boom. In contrast, during the years 1972-82, when the percentage of olim each year amounted to about 7.6 output per capita rose by the meager rate of $0.8 \%$ per annum (obviously, the oil price shock cum Yom Kippur War depressed output growth). In the later years, output growth was a declining trend the percentage of olim each year amounted to $16.5 \%$, output growth was meager 2.5 percent per anuum. 
Obviously, Table 2.3 is only suggestive for the role played by immigration and the massive investment, which accompanied its big waves, in growing the economy. Evidently, the statistics in Table 2.3 reflect the effects of business cycle fluctuations, external shocks, military conflicts, and the like, in addition to the migration waves.

\section{Migrant Characteristics}

The professional, social, attitudinal and behavioral characteristics of the 1990s Jewish exodus cohort proved to be distinctive. Immigrants came mostly from urban areas, with advanced education systems. Their skill (education) composition is heavily skewed towards high education levels; skewness in their relatively higher labor income (see Table 2.2). Their share in the population was sizable $-14.5 \%$. Their average family size (2.32 standard persons) was lower than the national average (2.64 standard persons). This indicates fewer dependents. Most important was their higher education level and consequently their higher labor income. The average number of schooling years of the new immigrants was 14.0, compared to the national average of only 13.3 . 
Table 2.2: The Skill, Age and Income of Immigrants from the FSU and the National Average, 1990-2011

\begin{tabular}{lcc}
\hline & $\begin{array}{c}\text { Immigrants } \\
\text { from the FSU }\end{array}$ & $\begin{array}{c}\text { National } \\
\text { Average }^{9}\end{array}$ \\
\hline Share in Total Population (\%) & 14.5 & 100 \\
$\begin{array}{l}\text { Household Size (numbers of standard } \\
\text { persons) }\end{array}$ & 2.32 & 2.74 \\
$\begin{array}{l}\text { Schooling Years Of Head of Household } \\
\text { (no.) }\end{array}$ & 14 & 13.3 \\
$\begin{array}{l}\text { Head of household with a bachelor degree } \\
(\%)\end{array}$ & 41.1 & 29.5 \\
$\begin{array}{l}\text { gross monthly labor income per standard } \\
\text { person (2011 NIS) }\end{array}$ & 4,351 & 4,139 \\
\hline
\end{tabular}

Source: Eilam (2014)

Even more striking was the percentage of heads of the households with bachelor degrees: $41.1 \%$ among the new immigrants, compared to a national average of just $29.5 \%$. The higher education level and the lower family size can presumably explain the income gap: the average labor income per standard person of the new immigrants was NIS 4,351, compared to a national average of only NIS 4,139. Noteworthy, this gap existed even though the new immigrants had lower work seniority than the established population.

The educational achievement figures of the immigrants from the FSU are impressive compared to the EU-15. Relying on data from the International Organization for Migration (IOM) and the OECD, Razin and Sadka (2014) report that only $18 \%$ of the stock of immigrants in the EU15 in 1990 and $24 \%$ in 2000 had tertiary education.

\footnotetext{
${ }^{9}$ Including immigrants 


\section{Catching Up}

Cohen and Hsieh (2000) show that average effective wages of native Israelis fell and the return to capital increased during the height of the influx in 1990 and 1991. By 1997 however, both average wages and the return to capital had returned to pre-immigration levels due to an investment boom induced by the initial increase in the return to capital. As predicted by the standard intertemporal model of the current account ${ }^{10}$, the investment boom was largely financed by external borrowing. Furthermore, despite the high educational levels of the Russian immigrants, the Russian influx did not lower the skill-premium of native Israelis. They explain this effect by the rise in Total Factor Productivity during the 1990s relative to stunningly low productivity increase through much of the 1970s and 1980s. Eckstein and Weiss (2004) develop a descriptive methodology for the analysis of wage growth of immigrants that is based on human capital theory. The sources of the wage growth are (1) the rise of the return to imported human capital, (2) the impact of accumulated experience in the host country, and (3) the mobility up the occupational ladder in the host country. Using data on established Israelis and immigrants from the former Soviet Union of Israel, they estimate Mincer-type wage equations jointly for the two groups. They find that in the ten years following arrival, wages of highly skilled immigrants grow at 8 percent a year. Rising return to skills, occupational transitions, accumulated experience in Israel, and an economy-wide rise in wages account for $3.4,1.1,1.5$, and 1.5 percent each. They do not reject the hypothesis that the return for experience converges to that of natives and that immigrants receive a higher return for their unmeasured skills. We find that there is some downgrading in the occupational distribution of immigrants relative to that of the established work force.

\footnotetext{
${ }^{10}$ See Razin (1995).
} 


\section{Upward Intergenerational Mobility and Income Inequality}

The second generation of Jews, whose parents immigrated from the former Soviet Union (FSU), experienced significantly higher upward mobility than all other ethnic groups. As documented by Aloni (2017), although the general association with parents' incomes within the FSU group is not very different compared to the population, their mobility relative to the national distribution is high, and the second generation finds its way even to the top percentiles. Table 3.1 shows the estimated probability of second generation outranking first generation in the full sample, and the groups' relative income rank convergence rates. Having higher probability to outrank parents highly depends on the relative income position of the group in the population's income distribution, thus, for example, Ethiopian and Arab children exhibit high upward mobility. But, controlling for their initial position, former Soviet Union (FSU) immigrants to Israel experienced the highest pace of upward mobility, while other groups converged to the mean slower.

Table 3.1 Intergenerational Mobility Indicators by Israeli Ethnic Groups

\begin{tabular}{lcccccc} 
& Israel & $\begin{array}{c}\text { Asia / N. } \\
\text { Africa }\end{array}$ & $\begin{array}{c}\text { Euro. / } \\
\text { America }\end{array}$ & FSU & Ethiopia & Arab \\
\hline & & & & & & \\
Probability of outranking parents & $40 \%$ & $49 \%$ & $37 \%$ & $58 \%$ & $75 \%$ & $59 \%$ \\
& & & & & & \\
& & & & & & \\
$\begin{array}{l}\text { Rank shift pace, controlling for } \\
\text { initial family position }\end{array}$ & -0.22 & -0.02 & - & $2.69^{* * *}$ & $-4.58^{* * *}$ & $-6.92^{* * *}$ \\
& $(0.17)$ & $(0.15)$ & - & $(0.16)$ & $(0.49)$ & $(0.16)$
\end{tabular}

Notes: First row is the probability of the child of reaching higher percentile in children's generation distribution compared to parents' average percentile in their income distribution. Second row is the regression results of child-rank on the population groups' dummies, controlling for parents' income rank using 100 percentile dummies. Base group is of families with Asia / North Africa origins. The sample is of children born amongst 1979 to 1982 matched to parents using administrative data.

Standard errors in parentheses; upper asterisks indicate--*** $p<0.01, * * p<0.05, * p<0.1$.

Source: Aloni (2017).

Upward mobility is also indicated in Figure 3.1. The Figure shows the distribution of children of parents from the bottom decile. Comparing the FSU immigrants and the general population, 
the former experienced a greater upward mobility, with children reaching higher earning ranks, dispersing more evenly across the deciles.

Figure 3.1: Earning Deciles of Children Born to the Bottom-Decile Parents

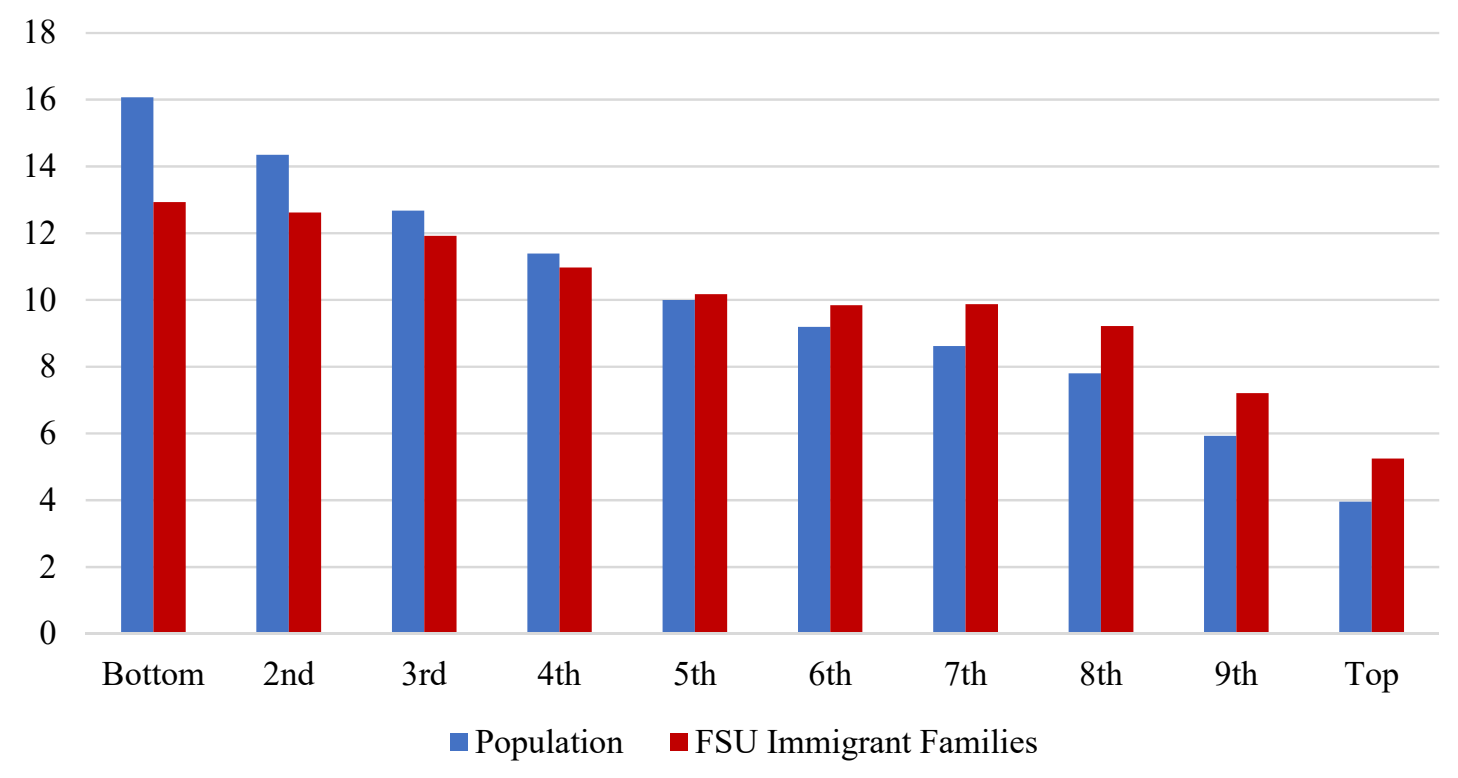

Source: Aloni (2017).

Figure 3.2 shows the probability of outranking parents by 5 percentiles, as a function of parents rank. Comparing these two groups to the general population suggests an increasing polarization. 
Figure 3.2: Probability of outranking parents by 5 percentiles by parents' quantiles

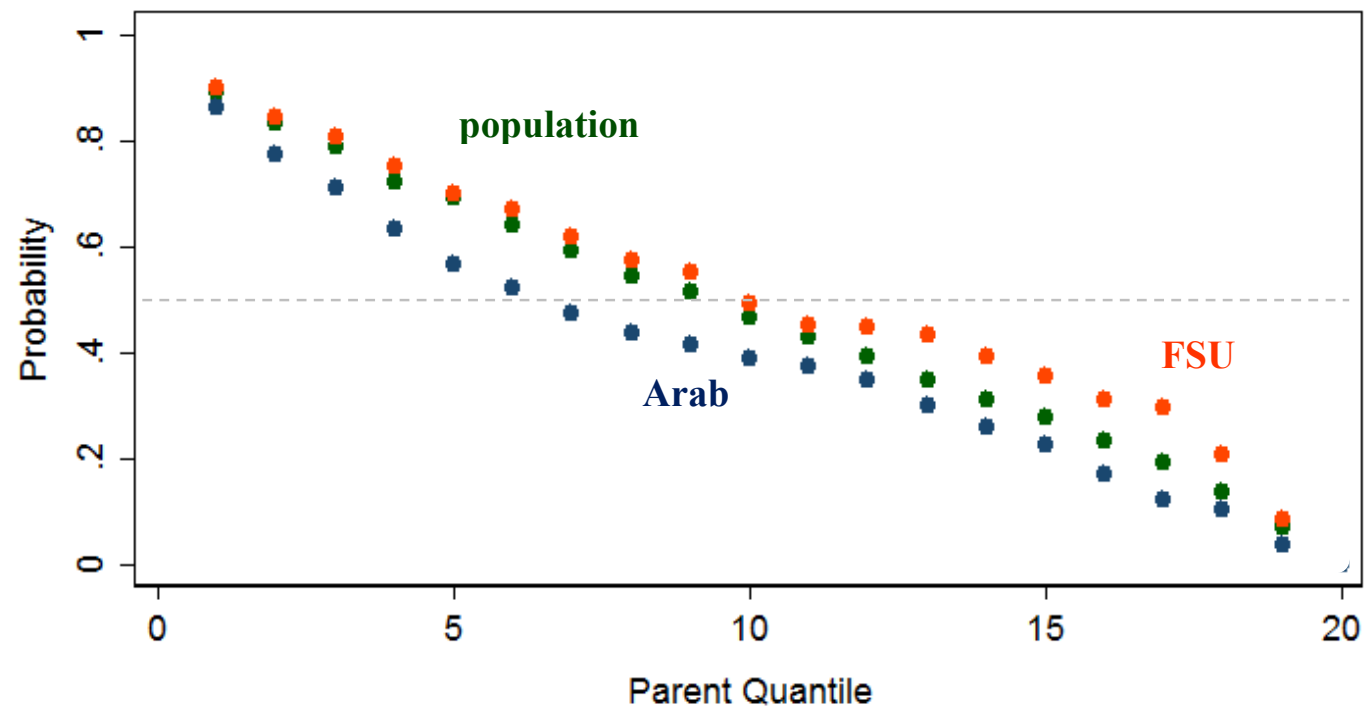

Note: Each point represents the proportion to have a children's rank higher than parents' by at least 5 percentiles, binned on parents' quantile. Population excludes FSU and Arab population. The difference between FSU and Arab groups is significant in a $95 \%$ significance level throughout.

Source: Aloni (2017)

These documented facts that the FSU group has higher upward mobility, along with the fact that the Israeli-Arab group experienced slower upward mobility, may increase inequality. This is because the FSU first generation immigrants' income is high compared to the population, while Israeli-Arab families have a lower income mean. Israel's fast development, facilitated by the integration into the world economy, and the inflow of high skill immigrants, came at a cost of growing income inequality, measured by both as market-based and redistribution-based Gini coefficients. Currently, Israel, along with the US and UK are at the top of market-forces generated inequality; and they do less than other OECD countries to reduce the inequality through the redistribution of income. ${ }^{11}$ See Figure 3.3.

${ }^{11}$ See Gornick and Jantti (2014) for a comprehensive report on income inequality and redistribution among rich countries. Krugman (2006) argues that to the extent that globalization explains rising income inequality in the United States, it is through the effect of international trade on the "skill 
Figure 3.3: Income Inequality and Redistribution

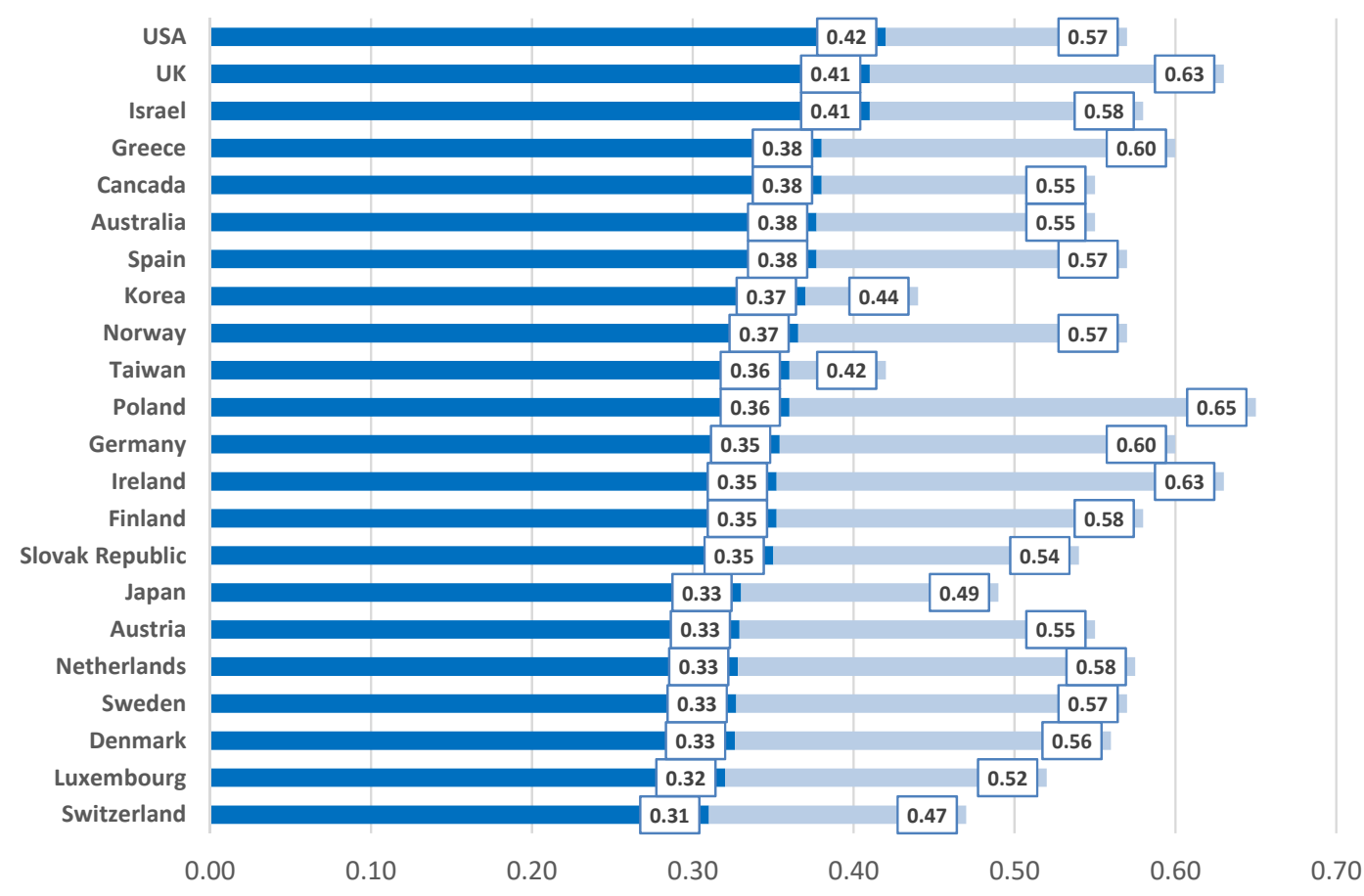

- GINI OF INCOME AFTER TAXES AND TRANSFERS GINI OF INCOME BEFORE TAXES AND TRANSFERS

Source: Gornick and Jantti (2014).

To gauge the size of income redistribution one can subtract the market based Gini coefficient

from the disposable income Gini coefficient. Israel's relatively high market-based inequality

coefficient, shown in Figure 3.3 , is driven by the large, and increasing, share of two relatively

poor minority groups in the population: Ultra-orthodox Israeli Jews (primarily males), and the

Israeli Arabs (primarily females ${ }^{12}$ ), stay out of the labor force. The rise in the share of these

premium", the gap between the incomes of college-educated workers and those without a college degree. What we know, however, is that rising inequality is not mainly about the rising skill premium. Only around a third of the rise in US inequality over the past generation is associated with a rising premium for education. Economic estimates indicate that the widening of the skill premium itself is more a result of "skill-biased technological change", a growing demand for highly educated workers due to the rising importance of information technology, than a result of globalization.

${ }^{12}$ Yashiv and Kasir (2011) write: "The most prominent phenomenon among Arab women is the high level of variation in the rate of participation. Its source apparently lies in the differences between "modern" and "traditional" women from the point of view of education, family status, number of children and proficiency in various skills (such as knowledge of English and the use of a computer). There appears to be a dichotomy or some type of dual market, in which "traditional" women almost never participate. This can explain the low rate 
groups in the total population is because the fertility rates among these minorities are much higher than the other groups in the population ${ }^{13}$ In addition, the emergence of highly educated, $\underline{\text { economically active large group of Israelis, reinforced by the high skill immigration of Soviet }}$ Jews, made the upper tail of the distribution thicker. Israel is not an outlier in the OECD countries with respect to the market-driven (pre-tax-cum-transfer) income inequality. However, Figure 3.4 indicates the time dimension of inequality. Disposable-income inequality in Israel, was roughly stable until the beginning of the 1990s, rose sharply thereafter, even though no such change occurs with respect to the market-generated inequality. Israel's level of redistribution of income falls short of many other OECD countries. A partial resolution of the issue, proposed by Razin, Sadka, and Swagel (2002), hinges on the political-economy effects of a rise in the dependency ratio. On the one hand, a higher dependency ratio means a larger pro-tax coalition, as the low income groups are net-beneficiary of the transfers from $\underline{\text { those who actively participate in the labor market. On the other, a higher dependency ratio puts }}$ $\underline{\text { a higher tax burden on the people around the median voter, as it is necessary to finance transfers }}$ to a larger share of the population. People for whom the costs of higher taxes outweigh benefits $\underline{\text { shift to the anti-tax coalition. Hence, the second factor dominates in many of other rich }}$ countries. That is, the political-economy equilibrium-tax rate declines when the dependency $\underline{\text { ratio rises. This would be the case until society ages enough so that the median voter is retired, }}$ at which point there is a discontinuous jump up in the tax rate and corresponding increase in the share of transfers. In other words, the increased share of the fiscal net-beneficiaries in the

of participation in comparison to other countries. "Modern" women have quite a high rate of participation, which also explains the simultaneous increase in participation and levels of education over time, together with additional cultural changes. The finding that participation rates among Arab women are very different from those observed in Western countries and among

Jewish women in Israel, though not significantly different from rates in Moslem countries".

13 Dahan (2007) explores the main factors behind the steep decline in the participation rate of Israeli men. He observes four factors responsible for the decline in participation rate between 1980 and 2001: increases in the population of students $(21 \%)$, the ultra-Orthodox $(21 \%)$, the disabled (32\%), and discouraged workers $(25 \%)$. 
population may have two opposing effects on redistribution policies. On the one hand, the political influence gained by low-income groups is persistently on the rise. This means that the $\underline{\text { median voter preferences shift over time in the direction of more generous welfare state. }}{ }^{14} \mathrm{On}$ the other hand, if the median voter, plausibly, does not belong the low-skill and non-working groups (as is probably also the case in Israel) then the increased share of the non-working and low-skill in the population may well lead policy-makers to lower taxes and transfers. Because, the increased fiscal burden which results for the large share of "net beneficiaries" adversely affect the median voter (she is a net contributor to the welfare system). The later affect dominates in Israel. Consequently, the entire redistribution system contracts.

Figure 3.4: Disposable Income Inequality* in Israel and Several EU-15 Countries, 19732013

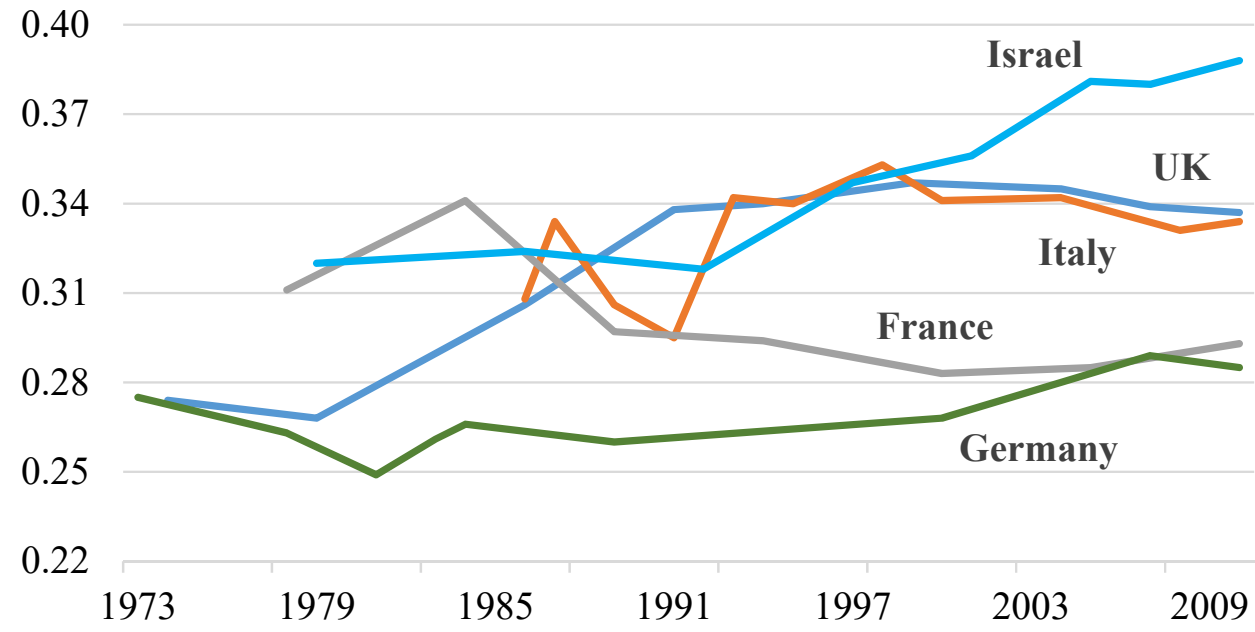

*Gini Coefficient

Source: Dan Ben-David (2015)

\footnotetext{
${ }^{14}$ About the voting right franchise in the US in the 1930s, Meltzer and Richard (1981) conclude: "In recent years, the proportion of voters receiving social security has increased, raising the number of voters favoring taxes on wage and salary income to finance redistribution. In our analysis the increase in social security recipients has an effect similar to an extension of the franchise."
} 
Figure 3.5 demonstrates that redistribution Gini coefficient upturned in 1989 and continues to rise until 2001. The implied more than a decade fall in income redistribution follows the Soviet-Jew immigration wave.

Figure 3.5: Total Income, Net Income-Inequality and Redistribution 1979-2015

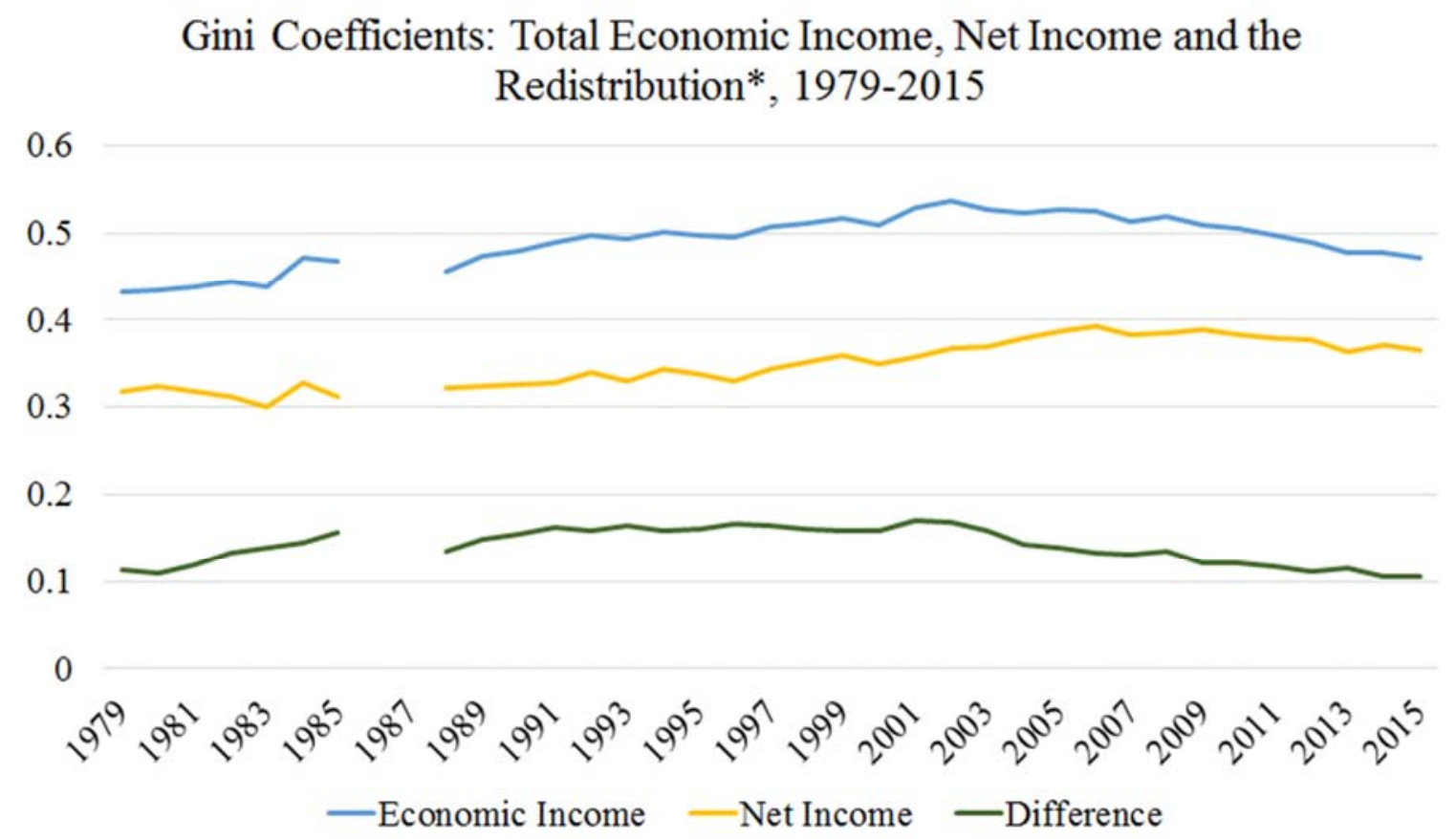

*The difference between total and net-income coefficients

Source: Momi Dahan (2017)

Notes:

The years 99'-02' do not include East-Jerusalem population. The years 12'-15' do not include the Bedouin population.

The unique position of Israel as a welfare state, among OECD countries, see Figure 3.6 highlights the low ranking of Israel in terms of its provision of social services per capita. ${ }^{15}$ High defense expenditures may have crowded out social services largely than in the other OECD countries. However, even though defense expenditures as a share of Israel GDP were following a distinct downward trend over the last 35 years, Israel diverges down in the provision of social expenditures, relative to the OECD countries. Figure 3.6 plots the social

\footnotetext{
${ }^{15}$ Social expenditures temporarily increased during the migration wave, thanks to one-shot absorption expenditures on new immigrants. They declined at the beginning of the 2000 s.
} 
expenditure, per capita, for Israel against selected group of countries. Israel is at the bottom of the group.

Figure 3.6: Social Expenditures Per Capita, selected countries

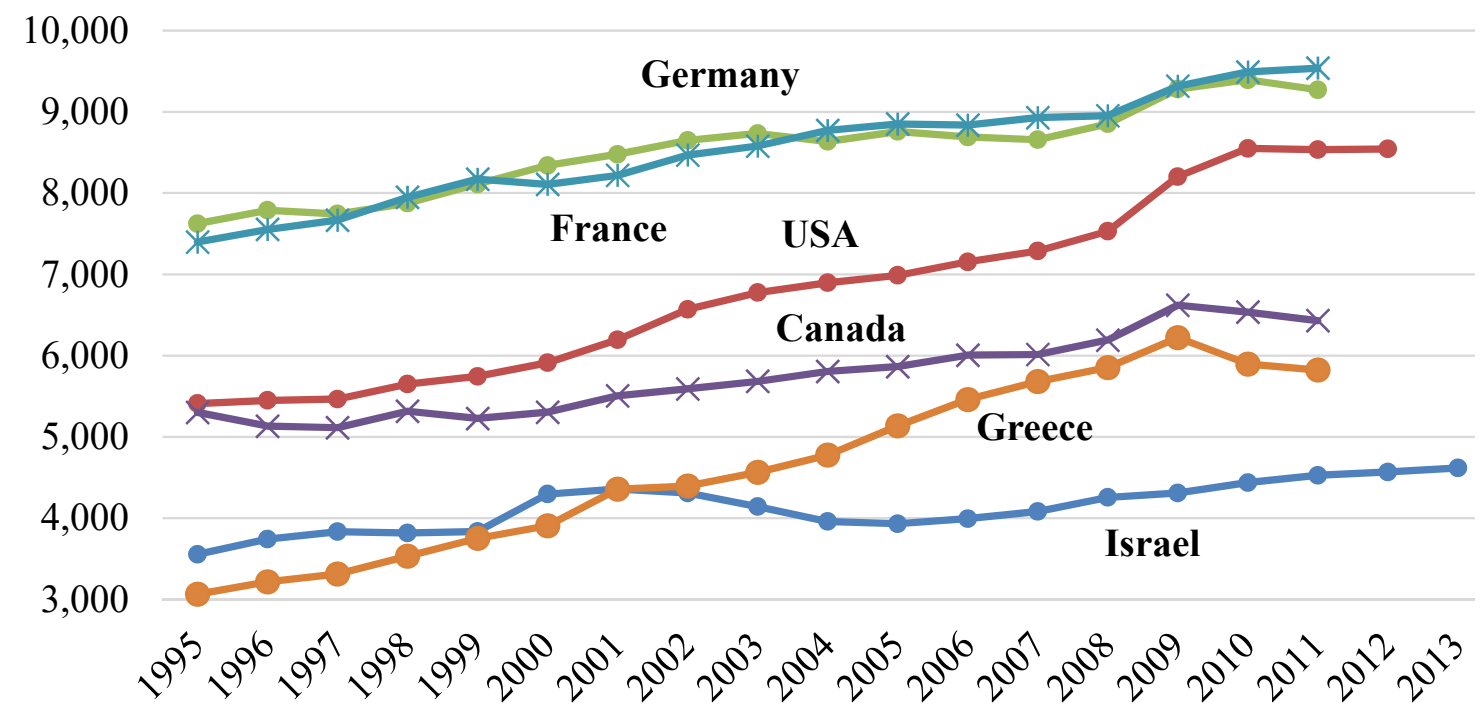

Note: Constant 2005 PPPs, in US dollars

Source: OECD library.

\section{Immigrants and the Political System}

Immigrants may also shift the balance of politics among ethnic groups, economic classes, or age groups, or may generate a massive political backlash. In Israel the political backlash have been moderate, whereas the change in political balance was substantial. Israel's Law of Return grants returnees immediate citizenship and consequently voting rights. An early study by Avner (1975) finds that the voting turnout rate of new immigrants had been markedly lower than that of the established population. This means that immigrants did not fully exercise their voting rights and did not therefore influence the political economy equilibrium in Israel as much as the established population. 
A similar migrant low voting turnout pattern is reported also by Messina (2007) and Bird (2011) for Western Europe. However, a later study about voting turnout pattern of new immigrants to Israel in the 2001 elections, conducted by Arian and Shamir (2002) reverse this finding for 2001. The new immigrants in this study are pre-dominantly from the FSU. Arian and Shamir (2002) find no marked difference in the voting turnout rates between these new immigrants and the established population. This is indeed a unique feature of the 1989-2001 immigration waves from the FSU. Relatedly,

Migration differs from the movement of other factor inputs (such as capital flows) in one fundamental way. Migrants become part of the society of the receiving country, including its evolving culture and politics. (The Swiss writer Max Frisch ironically declared: "We asked for workers. We got people instead.”) In Highly developed social welfare system in the receiving country may greatly complicate matters, as emphasized by Razin, Sadka, and Suwankiri (2011). While high-skilled and therefore high-wage migrants may be net contributors to the fiscal system, low-skilled migrants are likely to be net recipients, thereby imposing an indirect tax on the taxpayers of the destination country. Sooner or later, migrants may shift the balance of politics among ethnic groups, economic classes, or age groups, or may generate a massive political backlash. Migrants may change the nature of social interactions, with shifts in religion, ethnicity, and cultural practices.

\section{Political-Economy Theory ${ }^{16}$}

To understand better the balance of the political-economic forces at play, one has to analyze the political-economy forces at play in a general-equilibrium setup. Razin and Sadka

\footnotetext{
${ }^{16}$ Based on Razin and Sadka (2017).
} 
(2017) provide such a stylized general equilibrium model with free migration, where wages are endogenous and redistribution policy is determined by (endogenously determined) majority voting. ${ }^{17}$ They address the issue of how migration can reshape the political balance of power, especially between skilled and unskilled and between native-born and migrants, and consequently to political-economic equilibrium redistribution policy of the welfare state. The general equilibrium model could provide insights as to how in a "natural experiment" manner, an external supply-side shock triggers a wave of skilled migration. The shock then can change wages, migration flows, and political coalitions, so as to reshape the political-economy balance and the redistributive policies.

\subsection{Human Capital Investment}

There are just two types of workers: "skilled" (with a symbolS) and "unskilled" (with the symbol $U$ ). The wage per unit of labor of a skilled worker is $w$, whereas an unskilled worker earns a wage of $\rho w$ per unit of labor, where, $\rho<1$. All native-born $(N)$ are initially unskilled. However, a native-born can acquire education at some cost $(c)$ and becomes skilled. Individuals differ from one another through their cost of education: there is a continuum of native-born individuals, distinguished only by their cost of education. For notational simplicity, we normalize the number of native-born individuals to one. An individual is identified by her cost of education, so that an individual with a cost of $c$ is termed a c-individual. We assume for simplicity that the cost of education is uniformly distributed over the interval $[o, \bar{c}]$.

All native-born individuals are endowed with $E$ units of a composite good, the single good in this economy. All individual in elastically supply one unit of labor. If a c-individual acquires education and becomes skilled, her income ${ }^{18}$ is (denoted by $I_{S}^{N}$ )

$$
I_{S}^{N}(c)=(1-t) w+b+(E-c)(1+r)
$$

\footnotetext{
17 The model is based on Razin, Sadka and Swagel (2001a,b)

${ }^{18}$ Note that this specification assumes that capital does not depreciate at all.
} 
, where $t$ is a flat wage tax rate ${ }^{19} ; b$ is a uniform (lump-sum) per capita social benefit; and $r$ is the interest rate - the return to capital. If a c-individual decides not to acquire education and remain unskilled, her income (denoted by $I_{U}^{N}$ ) is

$$
I_{U}^{N}=(1-t) \rho w+b+E(1+r)(3.1)
$$

(Note that $I_{S}^{N}(c)$ depends onc, whereas $I_{U}^{N}$ does not)

Thus, there is a cutoff level of cost, $c^{*}$, so that all c-individuals with $c \leq c^{*}$ will choose to become skilled, and all the others (withc $\geq c^{*}$ ) will remain unskilled. This $c^{*}$ is defined by

$$
(1-t) w+b+\left(E-c^{*}\right)(1+r)=(1-t) \rho w+b+E(1+r) .
$$

Upon some re-arrangement, the cutoff level of the cost of education, $c^{*}$, becomes:

$$
(1-t)(1-\rho) w=c^{*}(1+r) .
$$

That is, $c^{*}$ is solved from the equality between the return to education and its cost. A $c^{*}$-individual is just indifferent between acquiring education (and thereby becoming skilled) or staying unskilled. Upon further re-arrangement, $c^{*}$ is defined by

$$
c^{*}=\frac{(1-t)(1-\rho) w}{(1+r)} \cdot(3.2)
$$

Note that $c^{*}$ may well exceed $E$, which means that those c-individuals with $c$ below but close to $c^{*}$ (which is endogenous) actually borrow in order to acquire education. Naturally, the payoff in terms of the higher wage would more than offset the borrowing cost. For those individuals $E-c$ is negative.

Also, note that we are employing a static framework within which all economic and political processes occur simultaneously with no time dimension. ${ }^{20}$ For instance, we do not distinguish between the time in which the education is acquired, and the time when the earnings occur. Similarly, capital earns its return $r$ at the same time it is employed.

The number of c-individuals with $c \leq c^{*}$ is the number of native-born skilled individuals. Denoting this number by $n_{S}$, it follows that

$$
n_{S}=\frac{c^{*}}{\bar{c}} \cdot(3.3)
$$

\footnotetext{
${ }^{19}$ In an unpublished version razin and Sadka extended the tax to apply to capital income as well.

${ }^{20}$ Such a framework is akin to a steady state in a dynamic model with rational expectations.
} 
Then, the number of native-born unskilled individuals, $n_{U}$, is thus given by

$$
n_{U}=1-n_{S} \cdot(3.4)
$$

Aggregate investment in human capital (education), denoted by $H$, and is then given by

$$
H=\int_{0}^{c^{*}} c \cdot \frac{1}{\bar{c}} d c=\frac{\left(c^{*}\right)^{2}}{2 \bar{c}} \cdot(3.5)
$$

Therefore, the aggregate stock of physical capital, $K$, is equal to

$$
K=E-H \cdot(3.6)
$$

There are also two types of migrants: the skilled who can earn a wage $w$ in the host country, and the unskilled who earn a wage of $\rho w$ in the host country. None of them has any initial endowment. The migrants come to the host country after they have already made and implemented the decision whether to acquire or not acquire education. Thus, it is exogenously given who is skilled and who is unskilled. In other words, the economy benefits from the skilled migrants because it does not have to pay for the cost of investment.

\subsection{Income Groups}

The income of skilled and unskilled migrants, respectively, is:

$$
I_{S}^{M}=(1-t) w+b(3.7)
$$

, and

$$
I_{U}^{M}=(1-t) \rho w+b \cdot(3.8)
$$

The income of the native-born as a function of $c$ is depicted in Figure 3.4. Note that $I_{S}^{N}(c)$ declines in a straight line until it reaches $c^{*}$, where

$$
I_{S}^{N}\left(c^{*}\right)=(1-t) w+b+\left(E-c^{*}\right)(1+r)=(1-t) \rho w+b+E(1+r)=I_{U}^{N} .
$$

The labor income of the unskilled native-born and the unskilled migrants is the same, but the total income of an unskilled migrant which is $(1-t) \rho w+b$ is definitely below the income of an unskilled native-born, the difference being the capital income enjoyed by the unskilled native-born, namely $E(1+r)$. The total income of a skilled migrant is definitely higher than the total income of the unskilled migrant, because of the higher wage earned by the 
skilled, whereas both have no other income. The income of the skilled migrants exceeds the income of the skilled native-born with $c>E$, but falls short of the income of the skilled nativeborn with $c<E$.

Figure 3.4: Income Groups as function of Cost of Education

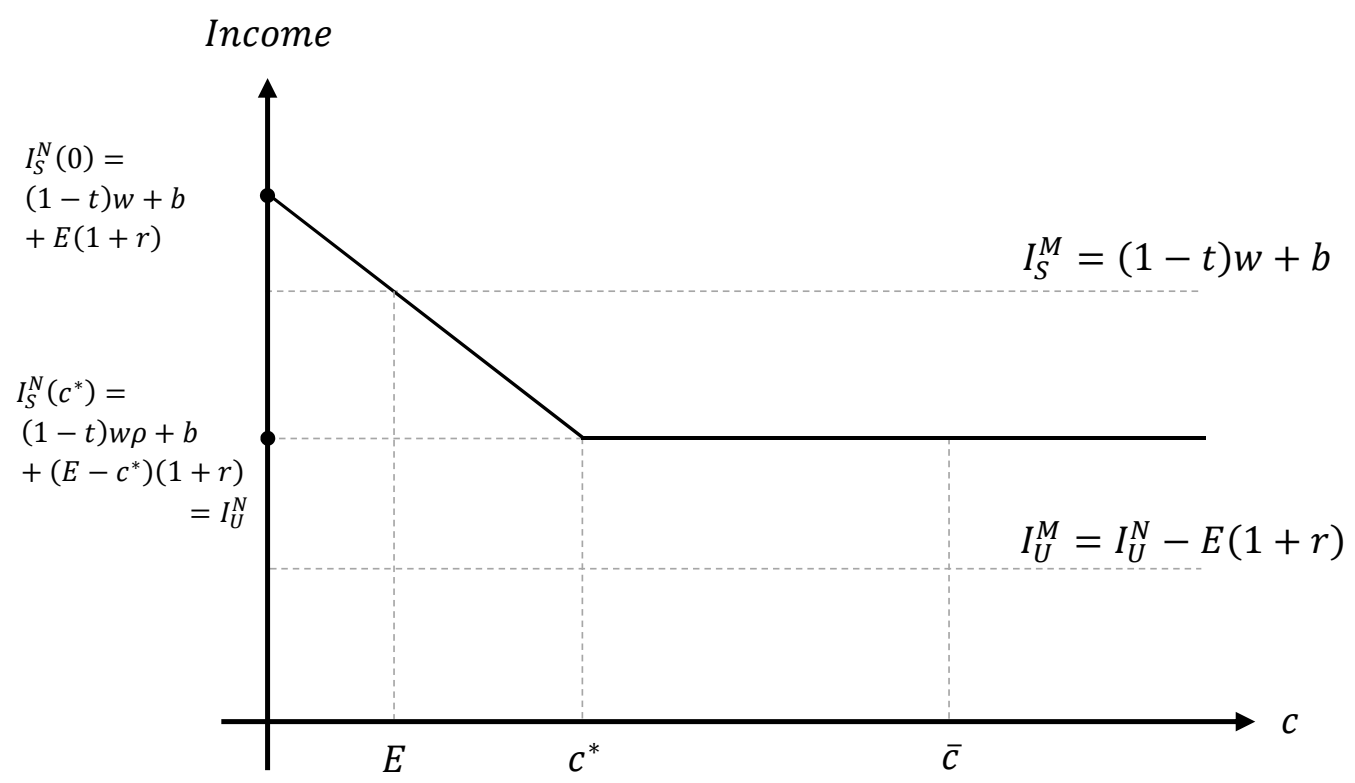

The income of a skilled migrant is $I_{S}^{M}=(1-t) w+b$, whereas the income of a skilled $c$ individual is $(1-t) w+b+(E-c)(1+r)$. Therefore, as long as $E-c$ is positive (i.e. the $c$-individual does not borrow in order to invest in human capital), then $I_{S}^{N}(c)>I_{S}^{M}$. However, if $E-c<0$ (i.e. the individual borrows in order to invest in human capital), then the income of the skilled migrant $\left(I_{S}^{M}\right)$ is greater than the income of the skilled native-born $\left(I_{S}^{N}\right)$. In sum, we have the following ranking of incomes:

$$
I_{U}^{M}<I_{U}^{N}=I_{S}^{N}\left(c=c^{*}\right)<I_{S}^{N}(c>E)<I_{S}^{N}(c=E)=I_{S}^{M}<I_{S}^{N}(c<E) .
$$

\subsubsection{Supply of Immigrants}

Recall that the country employs an unrestricted migration policy. We envisage an economy that allows any migrants to come. Thus, the decision whether to immigrate or no rests solely with the migrant. Each potential migrant has some reservation income, so that she will migrate if and only if she will be accorded a higher income in the destination country. 
Due to various factors (such as skill, family ties, age, etc.) this reservation income is not the same, but there is rather a continuum of such reservation incomes. Distinguishing between the two skills groups, we then assume that there is an upward sloping supply function for each skill group, depending on the income accorded to immigrants in the destination country. Denoting the number of skilled migrants by $m_{S}$, the supply function of skilled migrants is given by an iso-elastic function:

$$
m_{S}=B_{S}\left(I_{S}^{M}\right)^{\sigma_{S}}(3.9)
$$

, where $B_{S}$ and $\sigma_{S}$ are some positive parameters. Similarly, the supply function of unskilled migrants is given by

$$
m_{U}=B_{U}\left(I_{U}^{M}\right)^{\sigma_{U}}(3.10)
$$

, where $m_{U}$ is the number of unskilled migrants and $B_{U}$ and $\sigma_{U}$ are some positive parameters.

\subsection{Production and Factor Prices}

We employ a Cobb-Douglas production function

$$
Y=A K^{\alpha} L^{1-\alpha}, A>0,0<\alpha<1(3.11)
$$

, where $Y$ is gross domestic product, $A$ is a total factor productivity (TFP) parameter, and $\alpha$ is the capital-share parameter (and $(1-\alpha)$ is the labor-share parameter). Symbol $L$ indicates the total labor supply in efficiency units and is given by

$$
L=n_{S}+\rho n_{U}+m_{S}+\rho m_{U}(3.12)
$$

The competitive wage per efficiency unit of labor $(w)$ and the competitive interest rate $(r)$ are given by the marginal productivity conditions

$$
\begin{aligned}
& w=(1-\alpha) A\left(\frac{K}{L}\right)^{\alpha} \\
& \text {, and } \\
& r=\alpha A\left(\frac{K}{L}\right)^{1-\alpha},(3.14)
\end{aligned}
$$

, where we assume for simplicity that capital does not depreciate. 
The model exhibits the standard gains from trade argument. (see the appendix, which remind us who are gainers and losers from the flow of skilled migrants).

\subsection{Income - Redistribution System}

We employ a very simple system of redistribution. Wages are taxed at a flat rate oft. The revenues are distribution by a uniform per-capita transfer, $b$.

We assume that the migrants qualify for all the benefits of the welfare state, and they are naturally subject to the state taxes. Therefore, the government budget constraint is as follows:

$$
t w L=b\left(1+m_{S}+m_{U}\right)(3.15)
$$

, assuming that the government has no other revenue needs, except for redistribution. ${ }^{21}$ Note that it follows from equation (16) that $t$ and $b$ must be of the same sign. A positive wage $\operatorname{tax}(t)$ allows the government to accord a positive transfer $(b)$ to all. A subsidy to wages (namely, a negative $t$ ) requires the government to impose a lump-sum tax (negative- $b$ ) on all. When $t$ and $b$ are positive, the tax-transfer system is progressive. When they are negative, the system is regressive.

With unrestricted migration the flows of migrants $m_{S}$ and $m_{U}$ are determined by the migrants themselves according to their reservation incomes (embedded in the supply functions, (11) and (12)), and the income accorded to them in the host country. There are therefore only two policy variables - the tax rate, and the social benefit $b$. However, as the government is constrained by a balanced budget (condition (16)), it follows that there is essentially only one policy variables; once $t$ is chosen, all the other economic variables are determined in equilibrium, including the tax revenue $(t w L)$, the number of migrants $\left(m_{S}\right.$, and $\left.m_{U}\right)$, and $b$. Alternatively, alternatively, once $b$ is chosen, all the other economic variables are determined in equilibrium.

\footnotetext{
${ }^{21}$ One may wonder why there is no tax on the initial endowment $(E)$. In a distortive. However, in a dynamic setting which we mimic in a static framework, $E$ represents accumulated savings, and taxing it will be distortive. Furthermore, because all native-born possess the same initial endowment, taxing it in our static model does not distribute income across native-born income groups; but taxing $E$ amounts to transferring income from the native-born to the migrants static model such a tax is not.
} 
Choosing $t$ as the single policy variable, we note that there remain 15 endogenous variables

$$
w, b, r, c^{*}, I_{S}^{M}, I_{U}^{M}, n_{S}, n_{U}, I_{S}^{N}, m_{S}, m_{U}, H, K, Y, L .
$$

There are also 15 equations in the model - (2)-(9) and (10)-(16) - from which the endogenous variables are to be solved ${ }^{22}$.

The policy variable is chosen by some natural and plausible version of a majority voting, as described below.

Upon observation, we can see from equations (3.2) and (3.33) that the direct effect of the tax-transfer policy on the incomes of the unskilled native-born and the unskilled migrants is the same, and works through the net wage income $(1-t) \rho w+b$. For the unskilled migrant this is the only effect of the tax-transfer system. However, for unskilled native-born, there is also an indirect effect through capital income $I(1+r)$ (note that $r$ depends ont); but this indirect effect is of a second-order magnitude compared to the direct effect.

Similarly, the direct effect of the tax-transfer policy on the incomes of the skilled nativeborn and the skilled migrants is the same and works through the net wage income $(1-t) w+$ $b$. Here again, there is also and indirect effect on the income of the skilled native-born (but not on the income of the skilled migrants) through the capital income $(E-c)(1+r)$. Here again the indirect effect is of second-order magnitude.

Thus, all unskilled (both native-born and migrants) are affected by the tax-transfer policy mainly through $(1-t) \rho w+b$, whereas all skilled (both native-born and migrants) are affected mainly by $(1-t) w+b$. It is therefore natural that all the unskilled whose wage is only $\rho w$ would rather prefer to tax wage income and take advantage of all the skilled whose wage is higher $-w$. Thus, the most preferred policy of the unskilled entails a positive tax and a positive transfer. Therefore, if the unskilled (both native-born and migrants) constitute a majority, then the political economy equilibrium tax and transfer will be positive - a progressive tax-transfer system. However, due to the indirect effect, which applies only to the unskilled native born, the most-preferred tax and transfer policy is not necessarily the same for the unskilled native-born and the unskilled migrants. We then postulate that when the unskilled

\footnotetext{
${ }^{22}$ In addition, equation (1) defines $I_{S}^{N}$ as a function of $c$.
} 
form a majority, then the tax-transfer policy chosen is the most-preferred policy by the larger of the two sub-groups (the unskilled native-born or the unskilled migrants).

Similarly, the skilled (both native-born and migrants whose wage is higher than the unskilled) would opt to grant a subsidy to the wage, financed by a lump-sum tax. That is, they opt for negative $t$ and $b-$ a regressive tax-transfer policy. In this case too, there is also an indirect effect which applies only the skilled native-born. Thus, the most-preferred tax-transfer policy is not the same for the two sub-groups of skilled native-born and skilled migrants. In this case, too we postulate that the political-economy tax-transfer policy is the most-preferred policy of the larger sub-group.

Note that indirect effect of the tax-transfer policy, which works through the capital income, $(\mathrm{E}-\mathrm{c})(1+r)$ is not the same for all members of the skilled native-born sub-group (because it depends onc). In this case, we assume that the median voter within this group prevails.

If we keep all other parameter values constant and increase only the parameter value of $B_{S}$, we can isolate the effect of a supply side shock. That is, we give a positive shock to the supply of skilled migrants. We find that number of skilled migrants $\left(m_{S}\right)$ rises sharply. The skilled constitute now the majority $x_{S}+m_{S}>x_{U}+m_{U}$. As predicted, the political-economy taxtransfer policy becomes now regressive: $t$ and $b$ are negative. That is, there is a wage subsidy financed by a lump sum tax. In addition, the skilled migrants form the larger of the two skilled sub-groups, (i.e. $m_{S}>x_{S}$ ) and their most-preferred tax-transfer policy becomes now the political-equilibrium tax-transfer policy. Furthermore, the politically dominant sub-group of skilled migrants drives out all unskilled migrants $\left(m_{U}=0\right)$, by according them zero disposable income $\left(I_{U}^{M}=0\right)$.

Noteworthy, the unskilled native-born were initially the politically dominant sub-group and dictated their most-preferred progressive tax-transfer. Following the supply-side stock of skilled migration, the unskilled native-born lose their dominance to the skilled migrants who are now dictating their most-preferred regressive tax-transfer policy. Nevertheless, the unskilled native-born are better off, because the return to their capital income (namely, $r$ ) rises sharply (in unit of the all-purpose composite good). Even though the wage per efficiency unit falls, the sharp rise in the rate of interest (from 1.55 to 2.94) more than compensates the nativeborn unskilled for the wage decline. For the same reason, the skilled (native-born and migrants) 
are all better off. Thus, except for the unskilled migrants, who are driven out, all other income groups gain from the skilled-migration supply shock.

Note that the influx of skilled labor raises overall productivity of the labor force; consequently, it does also raise the tax revenue needed for shouldering the pre-existing redistribution policy. This force works towards more generous-redistribution, because it is fiscally less burdensome. Counteracting this pro-distribution force, however, is the rebalancing of the political coalition triggered by the increased share of higher-income skilled in the voting population. The result is that the emerging decisive voter reverses the pre-existing redistribution regime. ${ }^{23}$

It is worth explaining the model specific forces that totally drive out the unskilled migrants in the wake of the skilled-migration supply shock. The model assumes perfect substitutability between skilled and unskilled labor in production: each unit of time of an unskilled worker is equivalent to $\rho$ units of time of a skilled worker. Thus, unskilled migrants provide no productivity benefits to the skilled. At the same time, they constitute a fiscal burden Therefore, the new skilled-dominant coalition drive them out altogether by pushing their disposable income all the way to zero. The assumed perfect substitutability in production does serve to highlight the anti-unskilled-migration forces within the ruling skilled coalition.

\subsection{Implications}

The model attempt to rationalize the sharp rise in income inequality following the Soviet-Jew Exodus shock. It allows us to explore how migration supply side shock alters immigration patterns and, at the same time, reshapes the political-economy balance we develop a stylized political-economy model with free migration. Important political-economy mechanisms are at work: First, the influx of skill-immigrants depresses the incentives for unskilled migrants to flow in, though they are still free to do so. Second, the fiscal burden of redistribution policies diminishes from the viewpoint of the decisive voter. That is, the influx of skilled labor raises overall productivity of the labor force; consequently, it also raises the tax revenue needed for shouldering a redistribution policy. However, counteracting this pro-

\footnotetext{
${ }^{23}$ For numerical simulation, see appendix 3B.
} 
distribution force is the rebalancing of the political coalition, because the share of the increase in the skilled in the population. Therefore, the emerging decisive voter reverses preexisting the redistribution regime, notwithstanding the fall in the fiscal burden. Third, nonetheless, the unskilled native-born may well become well off, even though they lose their political influence. To sum up, the model prediction are as follows. First, the shock depresses the incentives for unskilled migrants to flow in, though they are still free to do so. Second, tax-transfer system becomes less progressive. Third, the unskilled native-born may well become well off, though they lose their political influence, which they had before the migration wave. All other native born income groups are also made better off. The positive economics predictions seem to consistent with data. The model helps interpret these result in a normative fashion.

The chapter describes a unique experience of Israel. Within a short time period in the early 1990s Israel received scores of migrants from the Former Soviet Union (FSU). Its distinctive feature was the migrants' high labor skill. It caused a sharp new upward trend of disposable income inequality but without a parallel change in market income inequality. That is, the welfare state took a sharp regressive turn. This underscores the role played by the post migration political balance, which triggered less redistribution.

\section{Appendix A: Gains to Native-born from Migration}

Like international trade in goods, there are gains and losses from the opening of national borders to labor mobility. A simple figure (Figure 3A.1) can serve to illustrate the gains from migration in our model. For concreteness, we illustrate the gains to the native-born from lowskilled migration. For simplicity, we assume that there are no taxes and benefits.

The down slopping curve in this figure is the marginal product of low-skilled labor. This curve is also the demand for this type of labor. 
There are S native-born high-skill labor. Free-migration number of high skilled immigrants is $F M_{S}$

In a closed economy with no migration, the equilibrium high-skilled wage is $w_{S}$.

GDP is equal to the area OGAD, of which the area HGA goes to the high-skill native-born and the area OHAD goes to the low-skill native-born.

\section{Figure 3A.1: The Gains from a High -Skill Migration}

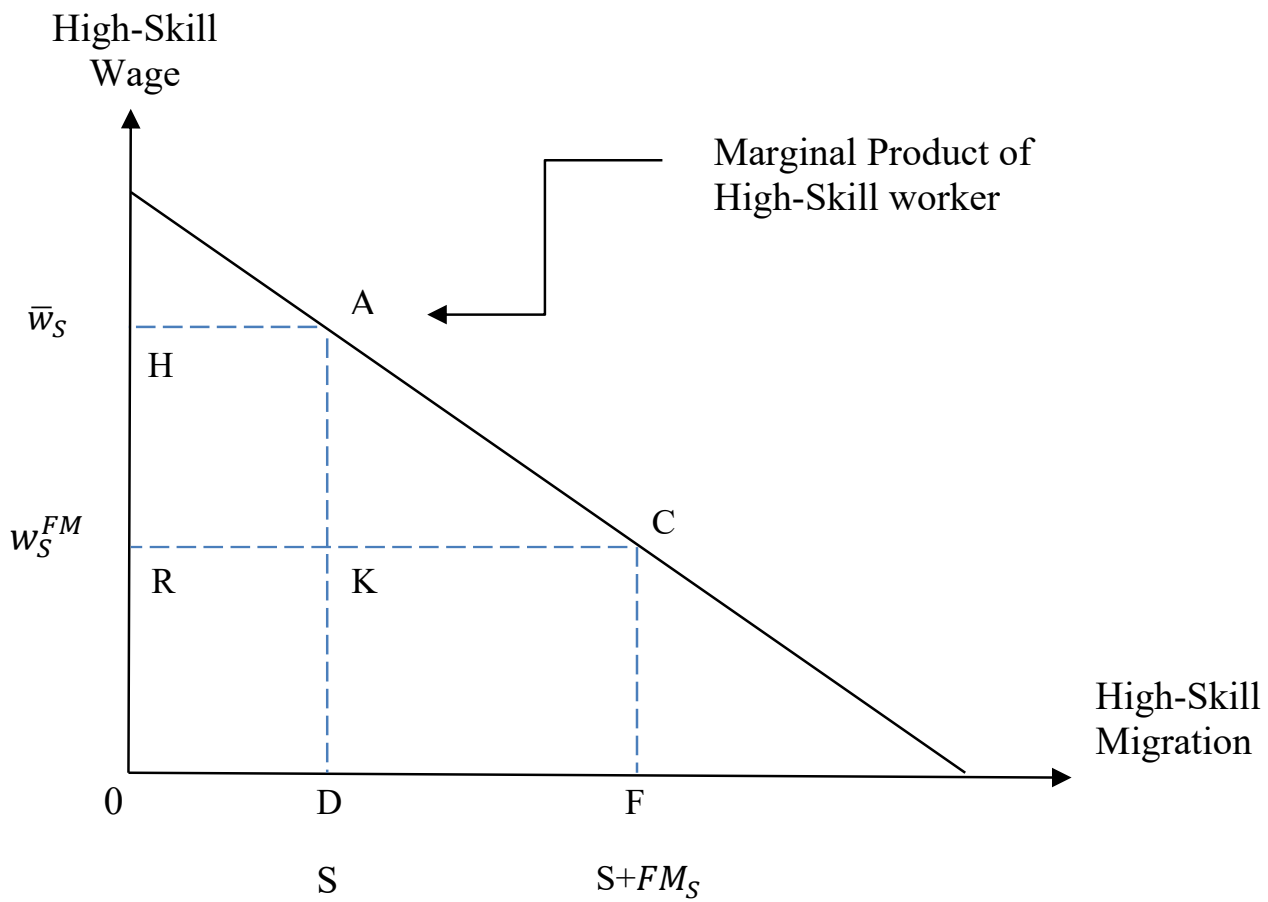

Suppose the high-skill migrants face a reservation wage of $w_{S}^{F M}$ in their countries of origin, which is below the threshold $\overline{w_{S}}$. If we allow for a free migration then $F M_{S}$ high-skilled migrants will come. The equilibrium wage will be: $w_{S}^{F M}$. GDP increases to OGCF (to both native-born and migrants).

An increase measured by the area DACF. A part of this increase (the area DKCF) goes to the low-skilled migrants, so that the total gains to all the native-born is the area AKC. Note, however, that not all native-born gain. The 
income of High -skill native-born drops to the area ORKD, so that they lose the area HAKR.

On the other hand, the income of the high-skill native-born exceeds the loss to the low-skill native-born.

Therefore, with a perfect, non-distortionary system of redistribution (via lump sums), the high-skilled native-born can more than compensate the low-skilled native-born, so that all native-born can gain from migration.

Note also that if the migration of high skill trigger either productivity gains (through external effects) or an increase in infrastructure investment (through policy effects) the marginal productivity curve would shift outwardly. Therefore, the wage of high skill under free migration need not fall.

Because a redistribution system (via wage taxation) is distortionary, the compensation possibilities are limited. It is not always the case that all native-born gain from migration. A similar conclusion holds in the case of high-skilled migration.

A striking result in Chapter 2 is that the migration supply shock benefit all income groups despite of the distortionary redistribution system and driven by political-economy forces.

\section{Appendix B: Numerical simulation of the Migration-Inequality Model}

The migration-inequality model, motivated by the Israeli experience with the wave of skilled migration from the FSU, simulates the effects of a supply shock of skilled migration on the political economy equilibrium tax-transfer policy.

We start with parameter values that entail the unskilled (both native-born and migrants) as a majority: $x_{U}+m_{U}>x_{S}+m_{S}$. This case is described in the first row in Table 3 . As

predicted, the political-economy tax-transfer policy is progressive: $t$ and $b$ are positive. Also, the unskilled native-born form a majority of the unskilled: $x_{U}>m_{U}$. 
Table 3: The Effect of a Supply Shock of Skilled Migration

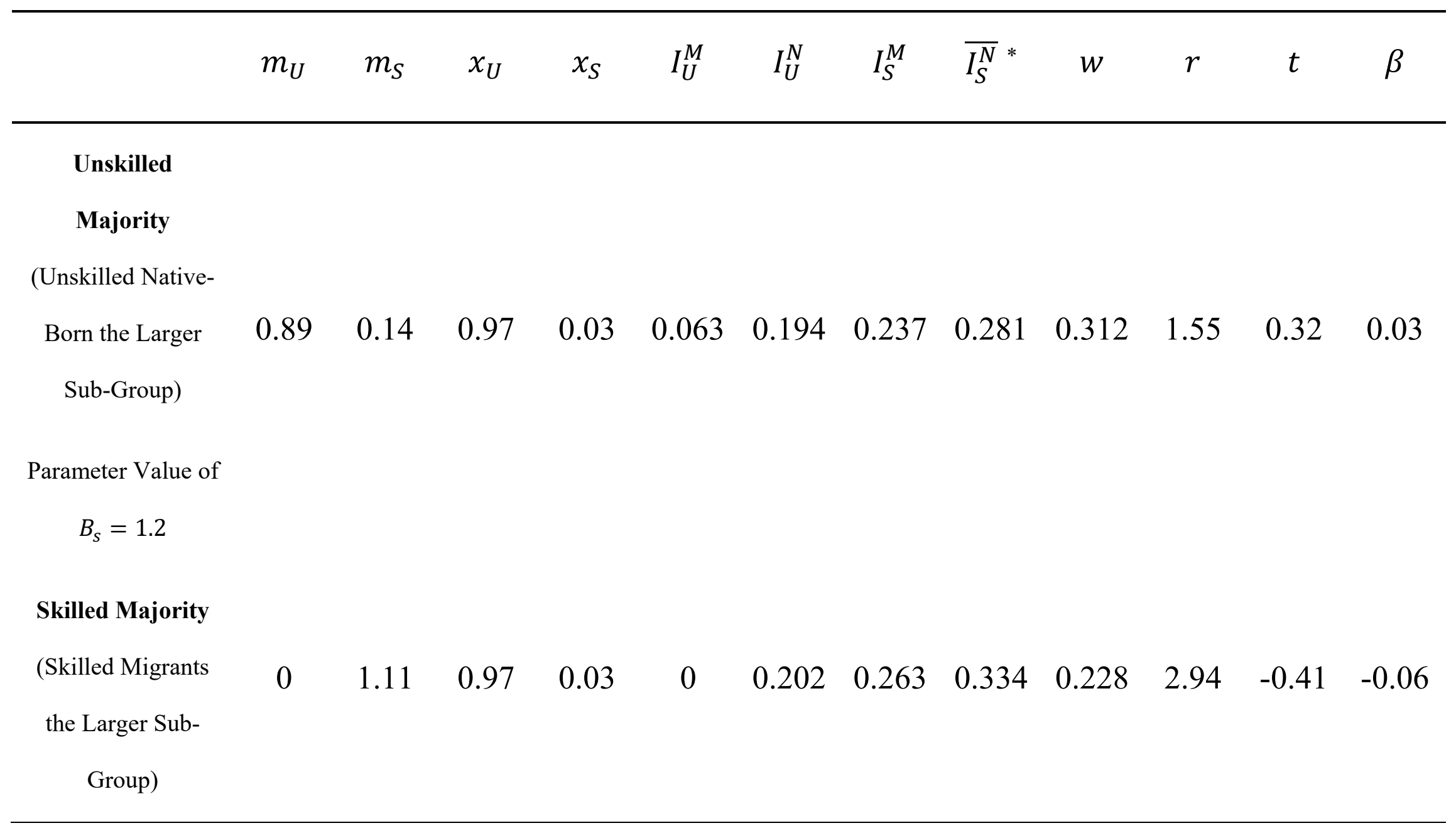




\section{Parameter Value of}

$$
B_{s}=8.2
$$

* Since the income of the native skilled population is not constant but a linear function of an individual's $c$, we report this group's average income. Notice that since the minimal income of a skilled native is equal to that of an unskilled native, we have that the income of the skilled immigrants lies in between them.

Other (Common) Parameter Values:

$$
B_{U}=56, \rho=0.18, \bar{c}=2, E=0.05, \alpha=0.33, \sigma_{S}=\sigma_{U}=1.5, A=1
$$


The political-economy tax-transfer policy is the most-preferred policy by the unskilled nativeborn.

We now keep all other parameter values constant and increase the parameter value of $B_{S}$. This supply-side sock triggers a wave of skilled migration. The results are shown in the second row of Table 3 . The number of migrants $\left(m_{S}\right)$ rose sharply from 0.14 to 1.11 . The skilled constitute now the majority: $x_{S}+m_{S}>x_{U}+m_{U}$. As predicted, the political-economy tax-transfer policy becomes now regressive: $t$ and $b$ are negative. Also, the skilled migrants form the larger of the two skilled sub-groups, (i.e. $m_{S}>x_{S}$ ) and their most-preferred tax-transfer becomes now the political-equilibrium tax-transfer policy. Furthermore, as can be seen from the second row of Table 3, the politically dominant sub-group of skilled migrants drives out all unskilled migrants $\left(m_{U}=0\right)$, by according their zero income $\left(I_{U}^{M}=0\right)$. Noteworthy, the unskilled native-born were initially the politically dominant sub-group and dictated their most-preferred progressive taxtransfer. Following the supply-side stock of skilled migration, the unskilled native-born lose their dominance to the skilled migrants who are now dictating their most-preferred regressive taxtransfer policy. Nevertheless, the unskilled native-born are better off, because the return to their capital income (namely, $r$ ) rises sharply from 1.55 to 2.94 (in unit of the all-purpose composite good).

\section{References}

Aloni, Tslil (2017) "Intergenerational Mobility in Israel," M.A. Dissertation, School of Economics, Tel Aviv University. 
Arian, Alan, and Michal Shamir, (2002). "Abstaining and Voting in 2001" in Arian, Alan, and Michal Shamir (eds.), the Elections in Israel - 2001. Israel Democracy Institute.

Arian, Alan, and Michal Shamir, (2002). "Abstaining and Voting in 2001" in Arian, Alan, and Michal Shamir (eds.), The Elections in Israel - 2001. Israel Democracy Institute.

Avner, Uri, (1975). "Voter Participation in the 1973 Election" in Arian, A. (ed.) Elections in Israel-1973. Academic Press, 203-218.

Avner, Uri, (1975). "Voter Participation in the 1973 Election" in Arian, A. (ed.) Elections in Israel-1973. Academic Press, 203-218

Ben-Bassat, Avi (2002) editor, The Israeli Economy, 1985 - 1998: From Government

Intervention to Market Economics, MIT Press, Cambridge, Mass.

Benhabib, Jess, and Boyan Jovanovic, B., (2012). Optimal migration: a world perspective, International Economic Review, 53(2), 321-348.

Ben-Porath, Yoram (1986), ed., The Israeli Economy: Maturing Through Crises, Harvard

University Press, Cambridge, Massachusetts.

Ben-Porath, Yoram, (1985). "The Entwined Growth of Population and Product, 1922-1982", in Yoram Ben-Porath (ed.), The Israeli Economy: Maturing Through Crisis. Harvard University Press.

Bird, Karen, (2011). "Voter turnout among immigrants and visible minorities in comparative perspective", in: Bird, Karen, Thomas Saalfeld, and Andreas M. Wüst (eds.), The Political Representation of Immigrants and Minorities: Voters, Parties, and Parliaments in Liberal Democracies. Routledge / ECPR.

Borjas, George J., (1999) “The Economic Analysis of Immigration,” Handbook of Labor Economics, Vol 3, Part A, pp. 1697-1760.

Borjas, George J., (1999) “Native Internal Migration and the Labor Market Impact of Immigration," Journal of Human Resources Spring 2006 vol. XLI no. 2 221-258.

Breslauer George, (1982) Khrushchev and Brezhenev as Leaders: Building Authority in Soviet Politics, London: George Allen \& Unwin. 
Card, David (1990), “The Impact of the Mariel Boatlift on the Miami Labor Market,” ILR Review January 1990 vol. 43 no. 2 245-257.

CIA, 1987. "Restructuring the Soviet Workplace: The New State Enterprise Law," OSA. https://www.cia.gov/library/readingroom/docs/DOC 0000499785.pdf

CIA, 1987. "Restructuring the Soviet Workplace: The New State Enterprise Law," OSA. https:/www.cia.gov/library/readingroom/docs/DOC 0000499785.pdf

Dahan, Momi (2007), "Why has the Labor-Force Participation Rate of Israel Men Fallen?" Israel Economic Review, Vol.5, No.2, 95-128.

Dahan, Momi (2017), "Income Inequality in the 2000s," mimeo, Hebrew.

Eckstein, Zvi, and Yoram Weiss (2004) "On the Wage Growth of Immigrants: Israel, 19902000," Journal of the European Economic Association, Volume 2, Issue 4, June , Pages 665-695.

Eilam, Nir, (2014). "The Fiscal Impact of Immigrants: The Case of Israel". MA thesis, The Eitan Berglas School of Economic, Tel-Aviv University.

Goldman, David F., (2013) "Israel’s Demographic Miracle," mimeo.

Goldstein, Itay, and Razin, Assaf, (2015). Three Branches of Theories of Financial Crises, Foundations and Trends in Finance, FnT Finance.

Gopinath, Gita (2004), Lending Booms, Sharp Reversals and the Real, Exchange Dynamics, Journal of International Economics, 62 (1), 1.

Gopinath, Gita, and Roberto Rigobon, (2007). Sticky borders. Quarterly Journal of Economics 123 (2):531-575.

Gopinath, Gita, and Oleg Itschoky, (2008), "Frequency of Price Adjustment and Pass-through," NBER Working Paper No. 14200

Gorbachev, Mikhail Sergeevich, (1987). October and Perestroika: The Revolution Continues. No. 276. Novosti Press. 
Gornick, Janet, and Markus Jäntti (2014), (eds.) Income inequality: Economic disparities and the middle class in affluent countries, Stanford University Press.

Gould, Eric and Omer Moav (2007) Israel's Brain Drain Israel Economic Review, Vol. 5, No. 1, pp. 1-22, 2007

Ilzetzki, Ethan, (2016) Review of Migration and the Welfare State: Why is America Different from Europe? By Assaf Razin and Efraim Sadka, Israel Economic Review Vol. 14, No. 1 (2016), 129-133.

Krugman, Paul. 2000. “The Price of Globalization?,” in Alan Greenspan (ed.) Global Economic

Integration, Jackson Hole Symposium.

Krugman, Paul (2006), "A Few Notes on Income Inequality", http://krugman.blogs.nytimes.com/2006/03/13/a-few-notes-on-income-inequality/? r=0.

Lucas, Robert E.B., (2014), ed. International Handbook on Migration and Economic Development, Edward Elgar.

Messina, Anthony M., (2007). The logics and politics of post-WWII migration to Western Europe. Cambridge: Cambridge University Press.

Narodnoe Khoziastvo USSR (1990), Statisticka Publishing, Moscow,.

National Academy of Sciences (1995), Research-Doctorate Programs in the United States:

Continuity and Change.

Neuman, Shoshana (1999) "Aliyah to Israel: Immigration under Conditions of Adversity IZA Discussion Paper No. 89 December

New York Times, JULY 24, 2015

Ottaviano, Gianmarco, and Giovanni Peri (2008), "Immigration and National Wages: Clarifying the Theory and the Empirics," NBER Working Paper No. 14188

Peri, Giovanni (2016), "Immigrants, Productivity, and Labor Markets," Journal of Economic Perspectives, Volume 30, Number 4, Fall 2016, Pages 3-30

Peri, Giovanni, Kevin Y. Shih, and Chad Sparber (2014) "Foreign STEM Workers and Native Wages and Employment in U.S. Cities," NBER Working Paper No. 20093 
Razin, Assaf and Efraim Sadka, (2017), How Migration Can Change Income Inequality? CEPR Discussion Paper 11244.

Rosefielde, Steven, (2001). "Premature deaths: Russia's radical economic transition in Soviet perspective", Europe-Asia Studies, vol.53, no.8, pp.1159-76.

Rosefielde, Steven and Bruno Dallago, (2016). Transformation and Crisis in Russia, Ukraine and Central Europe, London: Routledge.

Sachs, Jeffrey, (2012). "What I Did in Russia", March 14th. http://jeffsachs.org/2012/03/what-idid-in-russia/.

Sachs, Jeffrey, (2012). “Toward an International Migration Regime,” American Economic Review: Papers \& Proceedings, 106 (5): 451-455.

Sachs, Jeffrey, (2017), "Navigating the New Abnormal: The Populist Backlash,” Project Syndicate, February $3^{\text {rd }}, 2017$.

Yashiv, Eran, and Nitsa Kashir (Kaliner), (2011), "Patterns of Labor Force Participation Among Israeli Arabs," Israel Economic Review Vol. 9, No. 1 (2011), 53-101.

Yashiv, Eran and Nitza Kasir (2014) The Labor Market for Israeli Arabs, INSS, Tel Aviv

University.http://www.tau.ac.il/ yashiv/Israeli\%20Arabs\%20in\%20the\%20Labor\%20Market\%2

0--\%20Policy\%20Paper.pdf 